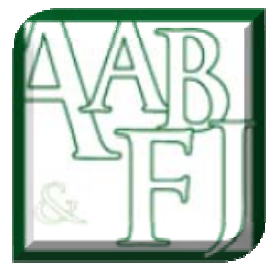

\title{
Strength of Bond Covenants and Bond Assessment Framework
}

\author{
Noel Yahanpath ${ }^{1}$ and SzeKee Koh ${ }^{2}$
}

\begin{abstract}
We examine bond covenants of 29 New Zealand bond issues between 2001 and 2007. Results from the study indicate that protection provided for bondholders is weak and limited. On average, only 2-3 types of covenants are embedded with the issues and only $27 \%$ of these covenants provide full protection to the bondholders. However, bondholders are not compensated for taking the additional risk. We propose an alternative assessment framework that directly assesses the level of protection offered to bondholders. We calculate the covenant quality score for the issues and classify them into four levels of protection: very high protection, moderate, low and very low. Recent legislative changes will go some way towards improving investor protection and confidence, but the effect is yet to be seen. This proposed scoring framework can be used by potential investors to complement the traditional credit ratings when making their investment decisions.
\end{abstract}

Keywords: Government policy and regulation, bond covenants, bondholder protection.

JEL classification: G18, G31, G33.

\footnotetext{
${ }^{1}$ Eastern Institute of Technology, Napier, New Zealand Email: nyahanpath@eit.ac.nz

${ }^{2}$ UWA Business School, The University of Western Australia
} 


\section{Introduction}

Credit risk is commonly defined as a lender's exposure to the possibility that a borrower will fail to perform its obligations under a loan or other credit instrument, principally the payment of principal and interest (Whitehead 2009). Given that lenders risk the loss of wealth in the face of management opportunism that only looks after the shareholders' interest, lenders may rely on the inclusion (at the expense of the borrowers) of covenants that restrict the management's actions and potentially furnish control rights to lenders (Jensen \& Meckling 1976). How extensively the levels of such covenants are included may be determined by the amount of borrower information that a lender possesses or can cheaply acquire (Denis \& Mihov 2003). If the lender is less well-informed, it is more likely to seek stricter covenants in order to more closely control a borrower's future activities. However, the widespread nature of debt decoupling ${ }^{3}$ may limit the effectiveness of covenants and weaken debt governance by dampening a lender's incentive to monitor borrowers or act in the interest of others to whom loans or credit exposure have been transferred. Nonetheless, in the absence of a liquid credit market, such as that of New Zealand's (NZ) debt market, lenders may still place greater reliance on covenants and monitoring, especially when covenants may still be the least costly means to managed credit risk.

In this paper, we examine bond covenants embedded in NZ bond issues between 2001 and 2007. Given that NZ has only a small and relatively illiquid secondary market for corporate bonds, lenders are likely to place a greater reliance on covenants to monitor management's actions and to protect their interests. This provides us with a natural experimental setting to test the strength of bond covenants embedded in debt issues: do issuing firms provide enough protection (against management opportunism) to lenders? A brief discussion on the evolution of debt issues in NZ is discussed next: Prior to 1987, equities were the most prevalent investments in NZ mainly because the NZ stock market rode on the bandwagon of the international bull market in the 1980s and enjoyed significant growth. From 1982, the NZ market rose about 600\%, compared with $250 \%$ in the US and $400 \%$ in Australia. However, the growth disappeared when share values dropped by $\$ 5.7$ billion in four hours, following a dramatic fall on Wall street on "Black Tuesday" in October 1987 (Grant 2010). As investors shunned the equity market, domestic companies looked for alternative sources of funding. Consequently, bonds became a popular fund-raising security in NZ; capital liquidity was scarce as banks tightened their credit criteria, and companies were forced to look to bond investors to raise their required funds. On the other hand, the poor performance of the NZ stock market also served to increase the popularity of bonds among investors who were looking for investments that returned a fixed income. In 1997, the first junk bond was issued in NZ at a rate of $18 \%$. Such issues were also a result of the difficulty in raising capital from private investors in NZ and the fact that banks would never finance $100 \%$ of a development for the issuing companies. For that reason, issuing companies look to the retail market of 'mum and dad' investors to cover their shortfall. During the three years that followed, there were an estimated 30 junk bond issues, raising more than \$200 million dollars (McIlroy 2000). However, in NZ, there is only a small and relatively illiquid secondary market for corporate bonds. The majority of NZ's corporate debt is issued in the three- to ten-year tenor of the yield curve. Typically, NZ firms have obtained short-term

\footnotetext{
${ }^{3} \mathrm{Hu}$ and Black (2008) suggest that ownership of debt customarily conveys (among other legal rights): a package of economic rights (to receive payment of principal and interest) and contractual control rights (to enforce, waive, or modify the terms of the debt contract). However, debt decoupling can have negative impact on financial stability: lenders' ability to shed risk weakens their incentives to assess and monitor debtors' repayment ability. Debt decoupling also impedes 'debt governance' - the interactions between creditors and firms (or other debtors) such as negotiations to address loan terms and conditions.
} 
(one-five years) funding from banks, and have turned to the corporate bond market for longer-term funding (Tyler 2006).

When a company collapses, equity investors (shareholders) are the greatest losers, but debt investors (bondholders) can sometimes be reimbursed some, or even all, of their investments. However, when a company does not collapse, risk can be transferred to debt investors through various practices, leaving these bondholders with the same fixed return and disproportionately higher risk. Equity holders then receive the benefits of higher returns for correspondingly less risk. Therefore, bonds issued in NZ are often embedded with a variety of restrictive covenants marketed as safety nets to protect investors from any expropriation of funds to shareholders. Specifically, these covenants are considered to be restrictive to the issuing companies because the companies may have to turn down their own investment or growth opportunities because of these constraints, and incur on-going costs in monitoring their compliance. To bondholders however, these covenants provide protection ${ }^{4}$ against any agency cost implications.

During the period 2006-2010, more than 50 NZ finance companies have failed, owing investors (mainly bondholders) over $\$ 6.5$ billion (Financial Markets Authority 2010). As a result of these collapses, in order to address the calls for tighter controls of the financial sector, the NZ government passed a series of new regulations ${ }^{5}$ (Dalziel 2007). For example, the previous Securities Markets Act of 1988 did not stipulate that the registration process for securities exchanges for a market operator must include an evaluation of the operational proficiency and suitability. Subsequent amendments were made to the Securities Markets Act of 1988, one of which was a criterion for a regulated exchange's trading rules and systems, including procedures for the proper management of large exposures, default risk and market disruption. These amendments to the Securities Markets Act came into force on February 29, 2008. On 14 September 2010, the NZ government introduced the Financial Markets (Regulators and KiwiSaver) Bill. Under this Bill, the Financial Markets Authority (FMA) was established to take over the functions of the Securities Commission of NZ. It combines the functions of the Securities Commission and the Government Actuary, with some regulatory functions of the Ministry of Economic Development and the Minster of Commerce. With the establishment of the FMA, NZ capital market regulation will take an historic step towards full implementation of global standards (Diplock 2010). In particular, the new regime introduces a system and procedures for prospectus review and registration. As per this model, the FMA will be responsible for the substantive examination of prospectuses, and there will be a minimum 'pause' period of five working days (extendable to ten at the FMA's request) during which the FMA will carry out this review (Tripp 2010). The main objective of this (examination) requirement is to ensure that issuers comply with the Securities Act and Regulations, and that there are no false or misleading statements or omissions of material. However, it is noted that even for the well-developed bond markets, such as the USA, the quality of covenants can be classified as strong, good or weak (Moody's 2006). This is mainly because the strength of covenants always leads to corresponding costs and benefits to the issuer (as well as to the investor). Therefore, even after the

\footnotetext{
${ }^{4}$ Yahanpath and Bellard (2004) find that the information provided in some bond issues is not perfectly transparent and distorted to some extent. This suggests that the bond market in New Zealand is inefficient particularly information wise, and that the bondholders may gain little protection from the protective covenants provided by issuer.

${ }^{5}$ In 2004, the International Monetary Fund (IMF) conducted a detailed assessment (Financial System Stability Assessment) of New Zealand's compliance with the International Organisation of Securities Commissions' (IOSCO) Objectives and Principles of Securities Regulation. The IMF also found gaps in the regulatory framework, which might inhibit the early detection of problems and, at times, enforcement (IMF 2004).
} 
implementation of the new regime under the FMA, it can be expected that some degree of variation in covenant quality will continue. ${ }^{6}$

In light of this situation, the aims of this paper are; firstly, to examine a sample of bond issues in NZ to evaluate whether the presence of bond covenants is an adequate mechanism to protect bondholders; and secondly, to develop a conceptual framework on covenant quality score as a second-level, risk-measurement indicator for potential bonds investors. We examined 29 bond issues and found that, while over 93\% of the sample companies embedded restrictive covenants in their debt issues, the issuing companies appear to have embedded only restrictive covenants that are most advantageous to themselves; ie, those for which the probability of (non-compliance) default by the issuers is least. This suggests that these assurances are inadequate for bondholders' protection. Next, using a questionnaire, we surveyed the respondents' views on the degree of importance of the various types of covenants. Using the responses, we developed a covenant quality score (CQS) that classifies bonds into four protection levels: very high, moderate, low and very low. The proposed framework is simple to use by potential bond investors and is a good complement to bond ratings by rating agencies.

\section{Theoretical Background}

A company seeking to finance an investment project has a number of means by which to raise the required funds. One choice available is to enter into contractual arrangements with providers of the funds in the credit markets. One such borrowing arrangement is the issuing of bonds. Specifically, bonds are claims on the company's final project returns which are sold directly by the company to investors. In return for their surplus funds, investors are provided with regular returns. Typically, bonds may contain two types of clauses: covenants and payments. In particular, a covenant confers upon lenders the right to place the company in default for specified values of the indicator ${ }^{7}$, thereby forcing the company to liquidate the project (Berlin \& Loeys 1988).

Bond covenants are a persistent phenomenon and prior studies argue that the presence of covenants in financial contracts is motivated and indeed rationalised (Tirole 2006), by their ability to mitigate agency problems (Jensen \& Meckling 1976; Smith \& Warner 1979) and aid in securing financing through the pledging of state-contingent control rights (Aghion \& Bolton 1992; Dewatripont \& Tirole 1994).

Rodgers (1965) is among the first to discuss the use of debt covenants in US debt contracts. He also discusses the history of the American Bar Foundation's Corporate Trust Indenture Project, under which the Commentaries were written. The Commentaries documented the various covenant provisions found in financial contracts in actual practice (Smith \& Warner 1979).

Indeed, if managers of the borrowing firms act in the lender's best interests in all states of the world, then there would be little reason for lenders to include complex debt contracts embedded with various covenants to ensure that their capital is eventually returned (with interest). However, it is well-known that managers will not always act in the best

\footnotetext{
${ }^{6}$ A future research opportunity is to study the impact of the FMA on the NZ corporate bond market in general and effectiveness of bond covenants in particular when sample data post-FMA establishment becomes available. It is also a possible research avenue to compare the covenant quality scores pre- and post-FMA, as an event study.

${ }^{7}$ Berlin and Loeys (1988) state that these indicators might be routine financial ratios used to measure the company's financial health or even the company's ability to make coupon payments on time. Bond covenants are written as functions of these indicators, and a company's inability to satisfy these covenants places the company in default.
} 
interests of their creditors. Jensen and Meckling (1976) for example, discuss the "nexus of contracts" view of the company and the implications of the agency cost between shareholders and bondholders. In particular, agency conflicts can exist between managers/shareholders and creditors that give rise to actions by borrowing firms that cause creditors some concerns. One potential conflict occurs when shareholders expropriate funds from bondholders either by increasing leverage, investing in new risky projects, or payments of dividends. Any of these actions will increase risk to the bondholders without a corresponding increase in return because returns to bondholders are fixed. Such concerns by bondholders further intensify in settings characterised by a substantial probability of distress ${ }^{8}$ where managers may make decisions that are advantageous to shareholders to the detriment of creditors (Guay 2008). Therefore, covenants are seen as to protect lenders from activities that prevent transfers to borrowers arising from the agency cost. Such provisions act as early warning "trip wires" that assist lenders to manage credit risk, permitting them to reassess a borrower's managers when weakened financial conditions increase the risk of opportunism and mitigate loss by renegotiating loans in anticipation of, or following a breach (Whitehead 2009). Hence, covenant violations identify a specific mechanism, the transfer of control rights, by which the misalignment of incentives can then be addressed by creditors (Chava \& Roberts 2008).

On the other hand, it may also be beneficial to borrowing firms to include covenants in their financing contracts. Bradley and Roberts (2004) for example, find that bond yields are lower, all else equal, when firms include covenants in their loan agreements. Although restrictions imposed by these covenants are costly to the firm, their benefit includes reduction in agency costs which translates into a lower cost of debt. As long as the costs of the constraints imposed by the covenants are less than the increase in the proceeds of the issue, firms will include covenants in their debt contracts. ${ }^{9}$

When covenants are embedded in the financing contracts, bondholders assume that they are protected against future events by the use of covenants, and that issuing companies relying on future funding will want to maintain a good reputation. Smith and Warner (1979) for example, argue for a costly contracting hypothesis and suggest that restrictive covenants can be incorporated to prevent shareholders from taking actions that reduce company value. However, if covenants are violated, it can also be very costly to borrowing firms. Upon breaching a covenant, control rights shift to the creditor, who can use the threat of accelerating the loan to choose his or her most preferred course of action or to extract concessions from the borrower to choose the borrower's most preferred course of action (Chava \& Roberts 2008). Chava and Roberts (2008) find that capital expenditure decline in response to a covenant violation by approximately $1 \%$ of capital per quarter - a $13 \%$ decline relative to investment prior to the violations. Their finding is consistent with the intuition provided by control-based theories, the transfer of control rights accompanying a covenant violation leads to a significant decline in investment activity as creditors intervene in order to thwart inefficient investment or punish managers for perceived misbehaviour (Aghion \& Bolton 1992; Dewatripont \& Tirole 1994; Gorton \& Kahn 2000). Chava and Roberts also

\footnotetext{
${ }^{8}$ Black, Brassil and Hack (2010) find that, following the increase in risk aversion associated with the Global Financial Crisis, investors have demanded stronger covenants. Recently issued corporate bonds have contained covenants such as negative pledges (to prevent the issuer from issuing debt that would rank higher than the bond) and change-of-control provisions (the investor has a 'put option' to sell the bond back to the issuer if there is a change of control at the company that could reduce credit quality, such as a leveraged buy-out). This suggests that borrowers regard covenants as one of the important protective measures for their investments.

${ }^{9}$ Bradley and Roberts (2004) argue that in the absence of covenants, the value of the firm's debt will be lower but the value of its equity will be higher. However, the decrease in the value of the debt due to agency cost will be greater than the increase in the value of the equity. Thus, stockholders would be better off if they could eliminate these agency costs. The sum of the value of the firm's outstanding equity, plus the proceeds from the debt issue would be greater, the lower the agency costs of debt (Bradley \& Roberts 2004, p.5, footnote 6).
} 
find that the investment response to covenant violations varies systematically with several different ex ante proxies for the misalignment of incentives and information asymmetry between borrowers and lenders. For example, punishments (ie, decline in investment) are more severe for (1) borrowing firms with no previous dealings with their current lender (due to little reputational capital), (2) firms with loans from a single lender relative to firms borrowing from a large lending syndicate (due to the moral hazard problem) \& (3) firms with relatively larger stockpiles of cash compared to firms with smaller cash holdings (due to free cash flow problem). Therefore, an issuing company may weigh up the benefits and costs of each contractual feature and determine a value-maximising set of terms in its bond contracts (Nash, Netter \& Poulsen 2003).

The seminal work of Smith and Warner (1979) was among the first to provide a detailed analysis of the different types of restrictive covenants in the indentures of public debt issues and the types of stockholder-bondholder conflicts that these covenants are designed to mitigate. In particular, they classified these restrictive covenants into four major categories: those that restrict the company's (1) investment policy, (2) payment of dividends to shareholders, (3) financing policies such as issuance of debt instruments (subsequent to the current issue) and (4) bonding activities, such as the specification of accounting technique and the required purchase of insurance. While subsequent studies into the use of debt covenants by other researchers attempt to reclassify and group restrictive covenants into other categories, they are generally similar to Smith and Warner's classification. Billett, King and Mauer (2007) for example, categorise their covenants ${ }^{10}$ into four main categories ${ }^{11}$ : (1) payouts restriction to equity holders and others (such as dividend restriction and restriction on share repurchase), (2) restrictions on financing activities (such as restricting the issuer from issuing additional subordinate, senior and secured debt), (3) event driven covenants (such as a decrease in credit rating or net worth or a poison put provision) and (4) restrictions on investment policy (such as asset sale clause, investment policy and merger restrictions).

In NZ, companies typically issue bonds with a variety of restrictive covenants which aim to restrict the issuers' actions and protect the bondholders. Using Smith and Warner's classification, we examined nine restrictive covenants ${ }^{12}$ that are used in NZ bonds to protect bondholders from expropriation of funds. We provide a brief discussion on each of these.

\section{Category 1: Investments policy}

\section{Covenant (A): Restriction on investment policy}

This gives a bondholder the right to direct what a company can invest in and how much risk it may take. Effectively, it gives the bondholder the power to veto actions against investment policies that are not in their best interests.

\section{Category 2: Payment of dividends}

Covenant (B): Restriction on dividends policy

This prevents any erosion of the value of the bond. Other things being equal, an increase in dividends will likely increase stock prices. When stock prices increase, bond prices will generally decrease. Therefore, an issue of a dividend may decrease

\footnotetext{
${ }^{10}$ Billett et al. (2007) find that of the 15 covenants studied in their paper, the most frequent covenants are secured debt restrictions (44\% of debt issue studies have this covenants embedded), cross-default provisions (51\%), asset sale clauses (65\%) and merger restrictions (65\%)

${ }^{11}$ Using a cluster analysis, Billett et al. (2007) suggest that the investment policy and payout restrictions tend to be in distinct covenant groups with each group including financing restrictions.

12 These covenants represent all the covenants that are used in NZ. Given that the choice of covenant categories model does not affect our research question (ie, the testing of the strength of bond covenants embedded in debt issues), we choose to follow Smith and Warner's (1979) classification framework as it is also the base model used by subsequent studies.
} 
the value of the bonds. Alternatively, payment of dividends may also be detrimental to the bondholders because any such payments will erode the company's ability to service its coupon payments or the repayment of principal to the bondholders. Generally, this restriction is achieved by linking dividend payments to earnings.

\section{Category 3: Financing policies}

Covenant (C): Restriction on additional leverage

Such a covenant places a requirement on an issuing company to seek the bondholders' consent before issuing a new secured debt. Therefore, it prevents the issuer from borrowing over and above a preset limit.

\section{Category 4: Bonding activities}

\section{Covenant (D): Minimum level of liquidity}

Liquidity relates to the ability of the company to meet its short-term obligations; it refers to overall solvency. ${ }^{13}$ If the issuing company fails to maintain a pre-agreed level of liquidity, it gives the bondholders the right to place the company in default.

Covenant (E): Poison put

This covenant gives bondholders the right to sell their bonds back to the issuer under certain conditions, such as an acquisition, a rating downgrade or a leveraged restructure.

\section{Covenant (F): Prohibition on selling assets}

The issuer has certain assets that are not used as security for the issue of the bond. However, this covenant provides assurance that these assets are provided as a protection for bondholders and cannot be sold, leased or otherwise disposed of.

Covenant $(G)$ : Security and prohibition on further security of assets

Some bonds are issued against the security of the issuer's asset base and guarantees are given that those assets will not be used as security for further issues. However, if these assets are used again, then no additional issue will rank ahead of the bonds being assured.

Covenant (H): Additional margin

This covenant explicitly provides the bondholders with the right to an additional margin or percentage if there is a breach of other covenants (such as a reduction in credit rating).

\section{Covenant (I): Call option}

The issuing company may have the option to call the bonds; that is, to redeem them from the bondholder. If these bonds are called when market interest rates have fallen, the bondholder can be disadvantaged by not being able to receive the high return offered. Therefore, strictly speaking, this is not a restrictive covenant on the issuing company. In contrast to the other eight covenants discussed above, an absence of such conditions will be more advantageous to the bondholders.

\section{Data and Research Design}

We first examined how extensively the nine bond covenants (as discussed in the preceding section) are used by the issuing companies to protect investors in NZ. We then developed a

\footnotetext{
${ }^{13}$ The solvency test has two parts: firstly, can the company pay its debts as they become due in the normal course of business and, secondly, is the value of the company's assets greater than the value of its liabilities, including contingent liabilities.
} 
conceptual framework on covenant quality score as a second-level risk measurement indicator.

A total of $156^{14}$ issuers were identified as having various numbers of bonds on issue in NZ. These included public companies, private companies and government bodies. We first eliminated the issues made by government bodies because the risk and characteristics of government issues can be very different from commercial issues. We then collected from a number of different sources, the corresponding covenants used by these companies for their bond issues. This involved going through the original prospectuses ${ }^{15}$ that were prepared at the time of issue, visiting the individual company websites and examining the database maintained by the New Zealand Companies Office. ${ }^{16}$ After eliminating bond issue statements due to missing information (such as missing prospectuses or insufficient documents to work out the types of restrictive covenants embedded in the bond issues), a total of 29 issuers were examined in our study. Of these 29 issuers, some had multiple bond issues during the period 2001 to 2007. Table 1 presents the final list of companies surveyed in this paper.

From the issue documents and/or trust deeds for the 29 issuers, we classified the types of covenants that were embedded with the issue, based on the classification found in the preceding section. When an issuer had multiple bond issues (within the same financial year or in different years prior to 2007), we examined the multiple issues collectively and reported the types of covenants used by this particular issuer. The information relating to each type of covenant was then examined for each bond issuer separately to evaluate the effectiveness of the covenants. An assessment grade, Y, L or N, was given, based on the following criteria:

$\begin{array}{cl}\text { Grade } & \text { Description } \\ \text { Y } & \text { A restriction that adequately protects the bondholder was placed on the issuer } \\ \text { L } & \text { A limited restriction was placed on the issuer } \\ \text { N } & \text { The company had no restrictions in that area }\end{array}$

\footnotetext{
${ }^{14}$ These issues were made (between 2001 and 2007) prior to the Securities Market Act that came into force in 2008. We do not include bond issues during the Global Financial Crisis (GFC) (ie, 2008 and 2009) because of the highly volatile financial market during that period. Also, we do not have a sample relating to the period after the establishment of the FMA, that can be included in this study to make a reasonable analysis. As mentioned in footnote 4, we believe that one potential extension of this study is to include bond issues after the establishment of the FMA to examine if there is a change in the use of covenants by NZ issuers. However, due to the lack of NZ samples available, we are limited to the testing of the samples prior to the FMA's establishment.

${ }^{15}$ We found that investment statements were often too wordy and difficult to read; that they sometimes contained ambiguities; and that important information was not always easily found. Thus we observed some degree of creative drafting of bond covenants which undermined these tools and mitigated the protection provided to investors.

${ }^{16}$ Accessible from www.companies.govt.nz/cms
} 
Table 1-Complete List of Companies and Issued Studied

\begin{tabular}{|c|c|c|c|c|c|}
\hline Company & $\begin{array}{c}\text { Company } \\
\text { Code }\end{array}$ & Issue \# & $\begin{array}{c}\text { On Issue } \\
\text { (Millions) }\end{array}$ & Issue year & $\begin{array}{l}\text { Time to } \\
\text { maturity }\end{array}$ \\
\hline \multirow{5}{*}{ ANZ National Bank } & \multirow{5}{*}{ ANB } & 20 & 150 & 2006 & 1.1 \\
\hline & & 30 & 150 & 2006 & 3.1 \\
\hline & & 40 & 350 & 2006 & 8.6 \\
\hline & & 50 & 250 & 2007 & 9.1 \\
\hline & & 60 & 350 & 2007 & 9.5 \\
\hline Blue Star Print Group Ltd & BLU & 20 & 105 & 2005 & 4.7 \\
\hline \multirow{8}{*}{ Infratil Limited } & \multirow{8}{*}{ IFT } & 40 & 20 & 2002 & 3.9 \\
\hline & & 60 & 85 & 2003 & 5.7 \\
\hline & & 70 & 120 & 2004 & 7.8 \\
\hline & & 90 & 77 & 2005 & 12 \\
\hline & & 110 & 57 & 2005 & 4.8 \\
\hline & & 130 & 0.68 & 2005 & 2.9 \\
\hline & & 140 & 112 & 2005 & 3.4 \\
\hline & & HA & 197 & 2007 & N/A \\
\hline \multirow{6}{*}{ Powerco Limited } & \multirow{6}{*}{ PWC } & 40 & 100 & 2004 & 3.2 \\
\hline & & 50 & 100 & 2004 & 5.2 \\
\hline & & 60 & 50 & 2004 & 7.4 \\
\hline & & 70 & 100 & 2005 & 2.3 \\
\hline & & 80 & 100 & 2005 & 4.7 \\
\hline & & 90 & 130 & 2005 & 9.6 \\
\hline \multirow{2}{*}{ PPCS Limited } & \multirow{2}{*}{ PPC } & 20 & 50 & 2004 & 1.2 \\
\hline & & 30 & 75 & 2006 & 4.9 \\
\hline Sky City & SKC & 20 & 150 & 2005 & 2.4 \\
\hline \multirow{3}{*}{ St Laurence } & \multirow{3}{*}{ STL } & 10 & 29 & 2005 & 2.5 \\
\hline & & 30 & 50 & 2006 & 3.4 \\
\hline & & FA & 1 & 2005 & 2.5 \\
\hline \multirow{3}{*}{ TrustPower } & \multirow{3}{*}{ TPW } & 20 & 108 & 2002 & 4.7 \\
\hline & & 30 & 50 & 2003 & 1 \\
\hline & & 60 & 54 & 2004 & 6.2 \\
\hline \multirow{2}{*}{ Vector Limited } & \multirow{2}{*}{ VCT } & 20 & 200 & 2003 & 1.2 \\
\hline & & 40 & 307 & 2006 & 4.4 \\
\hline \multirow{5}{*}{ Auckland International } & & 30 & 38 & 2004 & 0.9 \\
\hline & & 40 & 67 & 2004 & 1.6 \\
\hline & $A I A$ & 50 & 70 & 2004 & 3.6 \\
\hline & & 60 & 50 & 2005 & 4.8 \\
\hline & & 70 & 100 & 2005 & 7.8 \\
\hline Babcock \& Brown & BNB & 10 & 4 & 2006 & 3.7 \\
\hline BRI Networks & $B B N$ & 10 & 146 & 2004 & 1.9 \\
\hline 然 & 管 & 20 & 150 & 2006 & 4.9 \\
\hline Burns Philp Finance Ltd & $B P F$ & 10 & 173 & 2003 & 1 \\
\hline 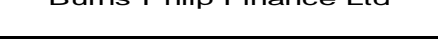 & 要 & 20 & 38 & 2003 & 3.9 \\
\hline CBA Capital & CBA & FA & 350 & 2005 & N/A \\
\hline Fidelity Capital & FDY & 10 & 75 & 2007 & 5.5 \\
\hline Fletcher Building Finance Ltd & $F B F$ & 10 & 112 & 2002 & 0.2 \\
\hline 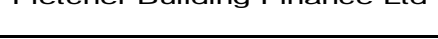 & (5) & 20 & 37 & 2002 & 2.2 \\
\hline Fonterra Co-operative & $F C G$ & HA & 102 & 2001 & N/A \\
\hline Generator Bonds & GTR & 10 & 129 & 2003 & $c$ \\
\hline 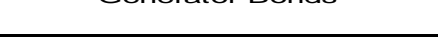 & MCB & 10 & 1.2 & 2006 & 3.7 \\
\hline Hellaby Holdings & HBY & 10 & 50 & 2006 & 3.4 \\
\hline HY-FI Securities & HYF & 10 & 95 & 2003 & 0.6 \\
\hline (19. & & 20 & 50 & 2003 & 0.6 \\
\hline New Zealand Finance & NZF & 10 & 20 & 2006 & 3.2 \\
\hline Origin Energy & OCF & $\mathrm{HA}$ & 200 & 2007 & N/A \\
\hline Rabobank Nederland & $\mathrm{RBO}$ & HA & 960 & 2007 & N/A \\
\hline Rural Portfolio Capital & RPC & 10 & 60 & 2007 & 3.3 \\
\hline Rural Portfolio Investments & RPI & 20 & 42 & 2004 & 1.3 \\
\hline Sky Network Television & SKT & FA & 200 & 2006 & N/A \\
\hline Strategic Finance & SFL & $\mathrm{HA}$ & 50 & 2007 & N/A \\
\hline TCNZ Finance Limited & TCN & 480 & 250 & 2006 & 5.2 \\
\hline 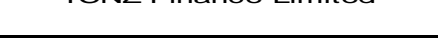 & & 490 & 150 & 2006 & 8.1 \\
\hline Works Finance (NZ) Limited & WKS & 10 & 200 & 2007 & 4.4 \\
\hline
\end{tabular}


We now discuss in detail how we use the quality assessment of the nine types of covenants studied in this paper.

Covenant (A): Restriction on investment policy

If a covenant complies strictly with the restrictions on investment policy, a $\mathrm{Y}$ is given. If the company specifically states that there are no limitations on the type of business it can carry out, an $\mathrm{N}$ is given. An $\mathrm{L}$ is given when the prospectus or trust deed specifically states that there are limitations on the type of business activities that are permitted or that there must not be a substantial alteration to its core business structure.

\section{Covenant (B): Restriction on dividend policy}

Typically, a restriction on dividend policy occurs when issuers are restricted to dividend payments if the company does not reach a pre-agreed level of earnings. However, such a condition is not used in NZ. Instead, NZ companies tend to disallow dividend payouts to shareholders when there are unpaid or overdue payments of principal or interest to bondholders. In some instances, NZ companies even self-impose penalties for breaches of this policy. Therefore, when paid dividends incur an additional penalty, a $\mathrm{Y}$ is given. An $\mathrm{N}$ is given when the investment statement limits dividends only as directed by the solvency test; in New Zealand, under the Companies Act 1993 section 4, all companies must pass the solvency test before making any distribution or repurchase of bonds or other issues. If the dividend policy limits when distributions can be re-established after a default but do not impose an additional penalty, an $\mathrm{L}$ is given.

\section{Covenant (C): Restriction on additional leverage}

Leverage has been determined in some companies' investment statements as "interest covered ratios" or "gearing ratios" expressed by (Debt:EBITDA); (Debt:Debt plus Equity); (EBITDA:Interest); and/or percentage (Debt:Tangible Assets). If a company pays a margin or premium when their gearing levels are breached, the company is given a Y. An L is given for any other limitation on leverage. An $\mathrm{N}$ is given if the company specifically states that there is no limitation on whether the company can issue new secured debt.

\section{Covenant (D): Minimum level of liquidity}

If a company gives an assurance that it will maintain a certain level of liquidity above the minimum, a $\mathrm{Y}$ is given. An $\mathrm{N}$ is given if the company specifically states that no particular liquidity level needs to be maintained. If a company gives an assurance of minimum net worth $^{17}$, an $\mathrm{L}$ is given.

\section{Covenant (E): Poison Put}

When any breach allows the bondholder to 'put' the bond automatically, a Y is given. When the issuer allows a 'put' to be made only in the case of late payment of principal or interest, liquidation or acquisition, an $\mathrm{N}$ is given. If the company allows the bondholder or trustee to 'put' the bond when a financial covenant has been breached (other than late payment of interest or principal, liquidation or an acquisition event) and that breach is not rectified within a certain number of days, or a bondholder may 'put' the bond during a re-marketing event, an $\mathrm{L}$ is given.

\footnotetext{
${ }^{17}$ Net worth does not actually relate to short-term liquidity, but may give assurance to bondholders of the overall true value should the company needs to liquidate at some stage.
} 
Covenant (F): Prohibition on selling assets

When a covenant exists to limit the sale, lease or disposal of assets, a $\mathrm{Y}$ is given. If the document specifically states that there is no limitation or there is a limitation but it allows the issuer to sell in excess of $15 \%$ of the assets, an $\mathrm{N}$ is given. If the limitation allows up to $15 \%$ of assets, an $\mathrm{L}$ is given.

Covenant (G): Security and prohibition on further security of assets

A $\mathrm{Y}$ is given if the bonds are secured and there is a prohibition against further security of assets, or when there is a limitation on the amount of indebtedness that is secured and the issuer will not create or permit any security interest to rank ahead of the bonds. An $\mathrm{N}$ is given if the company states that the issue is unsecured and/or there are no assurances as to the creation of new mortgages or charges against the issuer's assets. If the bonds are unsecured but the company gives an assurance that it will not allow any security over its assets without also providing that security to bondholders, an $\mathrm{L}$ is given.

\section{Covenant (H): Additional margin}

$\mathrm{A} \mathrm{Y}$ is given if an accruing margin is added for unpaid coupons and when an additional margin for other breaches also applies. An $\mathrm{N}$ is given if unpaid coupon is not specified and no margin is added for further breach of covenants. If an additional margin applies on unpaid coupons, reduction in credit rating, takeover event, or breach of financial covenant, an $\mathrm{L}$ is given.

Covenant (I): Call option

Given that this is not really a restrictive covenant against the issuing companies, we have reversed our assessment grade for this covenant. If the company specifically states that it will not call the bonds unless an event, such as liquidation or takeover of the company, necessitates the call, a Y is given. If the company may call at any time with little limitation, an $\mathrm{N}$ is given and when a call is available after a certain fixed period, an $\mathrm{L}$ is given.

\section{Results}

\section{The Extensiveness of Restrictive Covenants Used by Bond Issuers}

Table 2 presents the types of restrictive covenants used by the issuers, grouped according to four broad industry categories: (1) Banks (2) Industries (3) Non-bank deposit takers (including finance companies) and (4) Utilities (including energy distribution, road network and telecommunications). Inspection of Table 2 suggests that few companies give bondholders extensive assurance through covenants. Even for those companies that do provide some assurance, the majority of these assurances are inadequate for bondholder protection. 
Table 2 - Assessment grades

\begin{tabular}{|c|c|c|c|c|c|c|c|c|c|c|c|}
\hline Company & $\mathbf{A}$ & B & $\mathbf{C}$ & D & $\bar{E}$ & $\bar{F}$ & $\bar{G}$ & $\mathrm{H}$ & 1 & $\begin{array}{c}\text { Average } \\
\text { Return } \\
(\%)\end{array}$ & $\begin{array}{l}\text { Industry } \\
\text { Category }\end{array}$ \\
\hline ANZ National & $\mathrm{N}$ & $\mathrm{N}$ & $\mathrm{N}$ & $\mathrm{N}$ & $\mathrm{N}$ & $\mathrm{N}$ & $\mathrm{N}$ & $\mathrm{N}$ & $\bar{L}$ & 7.3 & Banks \\
\hline CBA Capital & $\bar{L}$ & $\bar{L}$ & $\bar{N}$ & $\mathrm{~N}$ & $\bar{N}$ & $\mathrm{~N}$ & $\mathrm{~N}$ & $\bar{N}$ & $\bar{L}$ & 8.8 & Banks \\
\hline Auckland International & $\mathrm{N}$ & $\mathrm{N}$ & $\mathrm{N}$ & $\mathrm{N}$ & $\mathrm{L}$ & $\mathrm{N}$ & $\mathrm{N}$ & $\mathrm{N}$ & $\mathrm{N}$ & 6.9 & Industrials \\
\hline Blue Star & $\mathrm{L}$ & $\bar{Y}$ & $\mathrm{Y}$ & $\mathrm{N}$ & $\mathrm{N}$ & $\mathrm{N}$ & $\mathrm{N}$ & $\bar{Y}$ & $\mathrm{~L}$ & 9.1 & Industrials \\
\hline Burns Philp & $\mathrm{N}$ & $\bar{N}$ & $\bar{N}$ & $\mathrm{~N}$ & $\bar{N}$ & $\mathrm{~N}$ & $\mathrm{~N}$ & $\bar{N}$ & $\bar{N}$ & 9.9 & Industrials \\
\hline Fletcher Building & $\mathrm{N}$ & $\bar{L}$ & $\mathrm{~N}$ & $\mathrm{~N}$ & $\mathrm{~N}$ & $\mathrm{~N}$ & $\mathrm{~N}$ & $\bar{L}$ & $\mathrm{~N}$ & 8.7 & Industrials \\
\hline PPCS Limited & $\mathrm{N}$ & $\bar{Y}$ & $\mathrm{Y}$ & $\mathrm{N}$ & $\mathrm{N}$ & $\mathrm{N}$ & $\bar{Y}$ & $\mathrm{Y}$ & $\mathrm{L}$ & 10.3 & Industrials \\
\hline Rural Portfolio Capital & $\mathrm{N}$ & $\bar{L}$ & $\bar{L}$ & $\mathrm{~N}$ & $\mathrm{Y}$ & $\mathrm{N}$ & $\mathrm{L}$ & $\mathrm{N}$ & $\mathrm{L}$ & 10.1 & Industrials \\
\hline Rural Portfolio Investments & $\mathrm{N}$ & $\bar{N}$ & $\mathrm{~L}$ & $\mathrm{~N}$ & $\bar{Y}$ & $\mathrm{~N}$ & $\bar{N}$ & $\bar{N}$ & $\mathrm{~N}$ & 10.8 & Industrials \\
\hline Sky City & $\mathrm{N}$ & $\mathrm{L}$ & $\mathrm{L}$ & $\mathrm{N}$ & $\mathrm{N}$ & $\mathrm{N}$ & $\mathrm{N}$ & $\mathrm{N}$ & $\mathrm{N}$ & 8 & Industrials \\
\hline Sky Network Television & $\mathrm{L}$ & $\mathrm{N}$ & $\mathrm{N}$ & $\mathrm{N}$ & $\mathrm{N}$ & $\bar{Y}$ & $\mathrm{~L}$ & $\mathrm{~N}$ & $\mathrm{~N}$ & 9.4 & Industrials \\
\hline St Laurence & $\mathrm{N}$ & $\mathrm{N}$ & $\mathrm{N}$ & $\mathrm{N}$ & $\mathrm{N}$ & $\bar{Y}$ & $\mathrm{~N}$ & $\mathrm{~N}$ & $\mathrm{Y}$ & 9.8 & Industrials \\
\hline Babcock \& Brown & $\mathrm{N}$ & $\bar{N}$ & $\mathrm{~N}$ & $\mathrm{~N}$ & $\bar{L}$ & $\mathrm{~N}$ & $\mathrm{~N}$ & $\bar{N}$ & $\mathrm{~N}$ & 9 & NBDT \\
\hline BBI Networks & $\mathrm{N}$ & $\bar{Y}$ & $\bar{L}$ & $\mathrm{~N}$ & $\mathrm{~N}$ & $\bar{Y}$ & $\mathrm{~N}$ & $\bar{L}$ & $\bar{L}$ & 8.3 & Utilities \\
\hline Infratil Limited & $\mathrm{N}$ & $\bar{L}$ & $\bar{Y}$ & $\mathrm{~N}$ & $\bar{L}$ & $\mathrm{~N}$ & $\bar{L}$ & $\bar{L}$ & $\mathrm{~L}$ & 8.4 & Utilities \\
\hline Origin Energy & $\mathrm{N}$ & $\bar{L}$ & $\mathrm{~N}$ & $\mathrm{~N}$ & $\mathrm{~N}$ & $\mathrm{~N}$ & $\mathrm{~N}$ & $\mathrm{~L}$ & $\mathrm{~L}$ & 10.2 & Utilities \\
\hline Powerco Limited & $\mathrm{N}$ & $\bar{Y}$ & $\mathrm{~L}$ & $\bar{L}$ & $\mathrm{~L}$ & $\frac{\mathrm{L}}{\mathrm{L}}$ & $\mathrm{L}$ & $\bar{L}$ & $\mathrm{~N}$ & 6.7 & Utilities \\
\hline TCNZ Finance Limited & $\mathrm{N}$ & $\mathrm{N}$ & $\mathrm{N}$ & $\mathrm{N}$ & $\mathrm{N}$ & $\mathrm{N}$ & $\mathrm{L}$ & $\mathrm{N}$ & $\mathrm{N}$ & 7 & Utilities \\
\hline TrustPower & $\mathrm{N}$ & $\mathrm{N}$ & $\mathrm{N}$ & $\mathrm{N}$ & $\mathrm{N}$ & $\mathrm{N}$ & $\mathrm{N}$ & $\mathrm{N}$ & $\mathrm{N}$ & 8.4 & Utilities \\
\hline Vector Limited & $\mathrm{N}$ & $\bar{N}$ & $\mathrm{~L}$ & $\mathrm{~L}$ & $\mathrm{~L}$ & $\mathrm{~N}$ & $\mathrm{~L}$ & $\mathrm{~N}$ & $\bar{Y}$ & 7.5 & Utilities \\
\hline Works Finance (NZ) Limited & $\mathrm{N}$ & $\bar{L}$ & $\mathrm{~N}$ & $\mathrm{~N}$ & $\bar{L}$ & $\mathrm{~N}$ & $\mathrm{~N}$ & $\overline{\mathrm{L}}$ & $\bar{L}$ & 9.8 & Utilities \\
\hline A & \\
\hline $\begin{array}{l}\mathrm{A} \\
\mathrm{B}\end{array}$ & \multicolumn{11}{|c|}{$\begin{array}{l}\text { Restriction on investment policy } \\
\text { Restriction on dividend policy }\end{array}$} \\
\hline $\mathrm{c}$ & \multicolumn{11}{|c|}{ Restriction on additional leverage } \\
\hline D & \multicolumn{11}{|c|}{ Minimum level of liquidity } \\
\hline $\mathrm{E}$ & \multicolumn{11}{|c|}{ Posion put } \\
\hline $\mathrm{F}$ & \multirow{2}{*}{\multicolumn{11}{|c|}{ Prohibition on selling assets }} \\
\hline G & \multicolumn{5}{|c|}{ Security and prohibition on furth } & & & & & & \\
\hline $\mathrm{H}$ & \multirow{2}{*}{\multicolumn{11}{|c|}{$\begin{array}{l}\text { Additional margin } \\
\text { Call Option }\end{array}$}} \\
\hline I & & & & & & & & & & & \\
\hline
\end{tabular}

Of the 29 issuers, only 2 issuers (Burns Philp and Trust Power) do not have any of the nine covenants embedded in their issues. This indicates that over $93 \%$ of the issuers do provide some form of protection for their bondholders. ${ }^{18}$ However, for those issuers who have embedded restrictive covenants in their prospectuses, the inclusions are not allembracing. On average, only 2-3 types of covenants studied are embedded. Furthermore, most of these covenants are limited restrictive covenants against the issuers; only $27 \%$ of these covenants provide complete protection to the bondholders. The remainder of this section provides an analysis of the prevalence of each covenant.

Only five companies have a covenant to restrict their investment policy. However, none of these covenants provides full protection to bondholders. The issuers still have flexibility in deciding their investment policy without much regard to the covenants. Thus, bondholders are still subject to the possibility of expropriation of funds.

Sixteen of the 29 companies make no comment about any restriction to their dividend policies. Eight have limited dividend policy protection. Only five companies impose a penalty on themselves by accruing an additional margin to the bondholder for any breach of dividend policies.

Eighteen companies do not have a covenant that restricts any increase in financial leverage; of these, eight companies state explicitly in their issue documents that there is no restriction on, or limitation of, the level of leverage. Only four companies have self-imposed penalties for breaches of leverage covenant, while another seven companies have limitations on leverage but the resulting protection is limited.

A covenant to assure a minimum level of liquidity appears to be the least prevalent restriction. Only two companies provide limited assurance to maintain a minimum net worth.

\footnotetext{
${ }^{18}$ The average return from all the sample issuers is $8.8 \%$ per annum. While Burns Philp offers a higher average return $(9.9 \%)$ than the sample mean to its investors, Trust Power offers a lower average return (8.4\%) than the sample mean return despite not having any restrictive covenants to provide any protections to its investors.
} 
Two companies, by design, allow their bondholders to 'put' the bond if any breach occurs, while seven others give a certain 'grace period' for the bondholder to 'put' the bond. Only fourteen issuers provide the 'put' option when the company is either late with payment of the principal or interest, is in liquidation or is subject to an acquisition. The remaining seven issuers make no statement about a bondholder's right to 'put' the bonds.

Only four of the 29 companies provide restriction on selling or leasing assets of the company. One allows up to $15 \%$ asset sales, and another allows up to $50 \%$ asset sales without the approval of the trustee. The majority of the companies examined remain silent on this important covenant.

A total of twenty companies do not make any assurances about the security of their assets. Of these, nine companies explicitly state that their issue is unsecured and give no assurance that they will not use the assets as collateral at some future period. The rest are silent on this restriction. Six companies also issue unsecured debt. Only three companies secure their bonds and place a prohibition on further security of assets.

Two companies add a penalty margin to coupon rate for either defaulting on coupon payments or a breach of other covenants. Ten companies have limited covenants for a margin to be added only in the event of a breach of financial covenant, a drop in credit rating or an acquisition. The remaining companies examined make no comment relating to additional penalty margins.

A total of 11 companies have a condition embedded in their issues that allow them to exercise the call option only after a specified period. Seven companies specifically state they can exercise the call option at any time. Two issuers specifically state that they cannot call the bonds unless liquidation or another extreme unforeseen event occurs, while the remaining eleven issuers make no indication on the call option in their investment statements.

Generally, for each covenant embedded with the bond issues, it is preferable that bondholders have full protection rather than limited or no protection against any agency cost that may trade off the value of the bonds they hold. If this is the case, then it is also reasonable to expect that bondholders would consider a $\mathrm{Y}$ rating to be higher than an $\mathrm{L}$ rating, and an $\mathrm{L}$ rating to be higher than an $\mathrm{N}$ rating. In view of that, we attempt to derive the extensiveness of the covenants by incorporating bondholders' perceptions of the degree of protection they receive from the individual covenants. In particular, we give a value of 2 for each $\mathrm{Y}$, I for each $\mathrm{L}$ and 0 for each $\mathrm{N}$. The values of 0,1 and 2 are somewhat arbitrary and we do not suggest that a covenant with full protection in favour of the bondholders (those covenants with the assessed grade of $\mathrm{Y}$ ) is preferred twice as much by bondholders compared to those covenants with partial limitations (those covenants with the assessed grade of $\mathrm{L}$ ). However, this mechanism provides some indication of the level of protection these covenants offer to a bondholder (from his or her perspective). Table 3 presents the relative magnitude of the extensiveness of usage of covenants. 
Table 3 - Companies by Issuing Category

\begin{tabular}{|c|c|c|c|c|c|c|c|c|c|c|}
\hline Company & $\bar{A}$ & B & $\mathrm{C}$ & $\bar{D}$ & $\bar{E}$ & $F$ & $\bar{G}$ & $\mathrm{H}$ & $\mathrm{T}$ & Total \\
\hline ANZ National & 0 & 0 & 0 & 0 & 0 & 0 & 0 & 0 & 1 & \\
\hline CBA Capital & 1 & 1 & 0 & 0 & 0 & 0 & 0 & 0 & 1 & \\
\hline Rabobank Nederland & 0 & 0 & 0 & 0 & 0 & 0 & 0 & 0 & 1 & \\
\hline Auckland International & 0 & 0 & 0 & 0 & 1 & 0 & 0 & 0 & 0 & \\
\hline Blue Star & 1 & 2 & 2 & 0 & 0 & 0 & 0 & 2 & 1 & \\
\hline Burns Philp & 0 & 0 & 0 & 0 & 0 & 0 & 0 & 0 & 0 & \\
\hline Fletcher Building & 0 & 1 & 0 & 0 & 0 & 0 & 0 & 1 & 0 & \\
\hline Fonterra Co-operative & 0 & 1 & 0 & 0 & 1 & 0 & 0 & 1 & 0 & \\
\hline Hellaby Holdings & 0 & 0 & 0 & 0 & 0 & 0 & 0 & 1 & 0 & \\
\hline PPCS Limited & 0 & 2 & 2 & 0 & 0 & 0 & 2 & 2 & 1 & \\
\hline Rural Portfolio Capital & 0 & 1 & 1 & 0 & 2 & 0 & 1 & 0 & 1 & \\
\hline Rural Portfolio Investments & 0 & 0 & 1 & 0 & 2 & 0 & 0 & 0 & 0 & \\
\hline Sky City & 0 & 1 & 1 & 0 & 0 & 0 & 0 & 0 & 0 & \\
\hline Sky Network Television & 1 & 0 & 0 & 0 & 0 & 2 & 1 & 0 & 0 & \\
\hline St Laurence & 0 & 0 & 0 & 0 & 0 & 2 & 0 & 0 & 2 & \\
\hline Babcock \& Brown & 0 & 0 & 0 & 0 & 1 & 0 & 0 & 0 & 0 & \\
\hline Fidelity Capital & 0 & 0 & 0 & 0 & 0 & 0 & 0 & 1 & 0 & \\
\hline Generator Bonds & 0 & 0 & 0 & 0 & 0 & 0 & 2 & 0 & 0 & \\
\hline HY-FI Securities & 0 & 0 & 0 & 0 & 0 & 0 & 0 & 0 & 1 & \\
\hline New Zealand Finance & 1 & 2 & 2 & 0 & 0 & 0 & 2 & 1 & 0 & \\
\hline Strategic Finance & 1 & 0 & 1 & 0 & 0 & 0 & 0 & 0 & 0 & \\
\hline BBI Networks & 0 & 2 & 1 & 0 & 0 & 2 & 0 & 1 & 1 & \\
\hline Infratil Limited & 0 & 1 & 2 & 0 & 1 & 0 & 1 & 1 & 1 & \\
\hline Origin Energy & 0 & 1 & 0 & 0 & 0 & 0 & 0 & 1 & 1 & \\
\hline Powerco Limited & 0 & 2 & 1 & 1 & 1 & 1 & 1 & 1 & 0 & \\
\hline TCNZ Finance Limited & 0 & 0 & 0 & 0 & 0 & 0 & 1 & 0 & 0 & \\
\hline TrustPower & 0 & 0 & 0 & 0 & 0 & 0 & 0 & 0 & 0 & \\
\hline Vector Limited & 0 & 0 & 1 & 1 & 1 & 0 & 1 & 0 & 2 & \\
\hline Works Finance (NZ) Limited & 0 & 1 & 0 & 0 & 1 & 0 & 0 & 1 & 1 & \\
\hline & 5 & 18 & 15 & 2 & 11 & 7 & 12 & 14 & 15 & 99 \\
\hline Maximum magnitude & 58 & 58 & 58 & 58 & 58 & 58 & 58 & 58 & 58 & 522 \\
\hline$\%$ over maximum protection & $8.6 \%$ & $31.0 \%$ & $25.9 \%$ & $3.4 \%$ & $19.0 \%$ & $12.1 \%$ & $20.7 \%$ & $24.1 \%$ & $25.9 \%$ & $19.0 \%$ \\
\hline
\end{tabular}


An inspection of Table 3 suggests that, despite covenants being marketed as a safety net for bondholders, NZ bondholders receive very little protection from the covenants embedded with the bonds issued. Based on the values of 0,1 and 2 for the levels of protection, if all bond issuers have all the covenants studied in this paper embedded in their issues, then the maximum value for full protection from all covenants is 522 (29 issues multiplied by 9 covenants with a value of 2). However, across all bond issues in our sample, the total degree of protection that NZ bondholders receive is only 99 out of the possible maximum value of 522 (i.e. 19\% level of protection, on average). This suggests that protection provided to NZ bondholders by way of the bond covenants is marginal.

\section{Covenants and Corresponding Weights}

Individual bondholders have individual investment portfolios and risk preferences, which may differ from other holders. These variances may also result in bondholders having different perspectives on the types of covenants that they deem important to their investment portfolios. Such perspectives may also be different from what the bond issue companies deem important and necessary to be embedded in their issues. Furthermore, it is possible for bondissuing companies to embed only certain covenants which are least possible for them to breach, to give bondholders the option (right) to exercise their rights under the restrictive covenants.

Therefore, in order to assign a weighting to each of the nine covenants, we designed a structured questionnaire using a five-point, Likert-type scale (where $1=$ least important and 5 $=$ most important) to measure the level of importance of the covenants. A total of 30 respondents were selected carefully, based on their knowledge about the use of bond covenants from a bondholder's perspective and availability. The questionnaire was emailed to these 30 respondents, and an online survey was conducted. The sample covers 20 entities including universities, financial advisors, share-brokers. The respondents represent both academia and corporate practitioners (with relative split 55:45 respectively) - although it was difficult to categorise many respondents as academics or practitioners, because the sample includes some academics with past industry experience and vice versa. The questionnaire invited respondents to rate each of the nine covenants, based on how important they thought the covenant was, from a bondholder's perspective. Table 4 reports the responses.

Table 4 - Survey results - The most important covenants deemed by bondholders

\begin{tabular}{|c|c|c|c|c|c|c|c|}
\hline & $\begin{array}{c}\text { Least } \\
\text { Important }\end{array}$ & & & & $\begin{array}{c}\text { Most } \\
\text { Important }\end{array}$ & & \\
\hline & 1 & 2 & 3 & 4 & 5 & Mean & Rank \\
\hline C) Restriction on increasing leverage & $0 \%$ & $0 \%$ & $4 \%$ & $59 \%$ & $37 \%$ & 4.33 & 1 \\
\hline D) Required minimum levels of liqudity & $4 \%$ & $0 \%$ & $22 \%$ & $48 \%$ & $26 \%$ & 3.93 & 2 \\
\hline A) Restriction on investment policy & $4 \%$ & $7 \%$ & $15 \%$ & $48 \%$ & $26 \%$ & 3.85 & $3^{\star}$ \\
\hline G) Securities and prohibition of futher securities of assets & $0 \%$ & $4 \%$ & $37 \%$ & $30 \%$ & $30 \%$ & 3.85 & $3^{\star}$ \\
\hline B) Restriction on dividend policy & $4 \%$ & $7 \%$ & $26 \%$ & $37 \%$ & $26 \%$ & 3.74 & 5 \\
\hline H) Additional margin & $0 \%$ & $11 \%$ & $56 \%$ & $22 \%$ & $11 \%$ & 3.33 & 6 \\
\hline E) Poision put & $4 \%$ & $15 \%$ & $37 \%$ & $37 \%$ & $7 \%$ & 3.30 & 7 \\
\hline F) Prohibition on selling assets & $7 \%$ & $19 \%$ & $37 \%$ & $30 \%$ & $7 \%$ & 3.11 & 8 \\
\hline I) Call option & $15 \%$ & $30 \%$ & $22 \%$ & $22 \%$ & $11 \%$ & 2.85 & 9 \\
\hline
\end{tabular}

Based on the responses, the covenant on financial leverage is deemed to be the most important (mean of 4.33) and the call option is deemed least important (mean of 2.85). In Tables 2 and 3, we found that the magnitude of the extensiveness of the restriction on increasing leverage has a percentage of $25.9 \%$ over the maximum protection and is not the covenant that is most widely used by NZ issuing companies in their bond issues, as NZ 
companies tend to embed restriction on dividend policy in their bond issues. However, a comparison with the result in Table 3 also suggests that NZ companies do embed call option in their issues (providing a percentage of $25.9 \%$ over the maximum protection) as often as the use of the restriction on increasing leverage. These findings imply that NZ issuing companies are not providing the right covenants, according to what bondholders perceive as important for their benefit or protection. Instead, NZ issuing companies may be embedding only restrictive covenants that are most advantageous to themselves; ie, those for which the probability of (non-compliance) default by the issuers is least.

\section{Covenant Quality Score and Bond Rating}

A credit rating can be used to assess the credit-worthiness of a bond issuer, whereby bonds can be broadly classified into: (1) investment grade bonds and (2) junk bonds. To assess the credit-worthiness of the issuing company, rating agencies typically use a range of indicators, including financial, non-financial and qualitative information. However, the quality of covenants is not directly included in the rating methodologies used by rating agencies (Standard and Poor's 2009). Therefore, our aim is to develop a Covenant Quality Score (CQS) which we believe will be a valuable input to the overall bond-rating framework. Moody's (2006) has proposed a framework for the evaluation of the relative quality of each key covenant individually, in a package and of the covenant package as a whole, assigning a score of CQ-1 to CQ- $3^{19}$ to the indenture. Though Moody's framework is a useful classification, it stops short of a numerical score. In this paper, we use Moody's line of argument and proposed a framework for assigning a numerical score for covenant quality for each key covenant individually, in a package and of the covenant package as a whole. Our emphasis has been to develop a simple, user-friendly modelling framework that is useful particularly to smaller corporate bond markets.

The methodology we use here is very simplistic, due mainly to the limited availability of data on corporate bonds in the NZ debt market. There are many interesting opportunities to expand upon this work by applying some of the more advanced models in larger debt markets. Notwithstanding the above, Vojetek \& Kocenda (2006) state that the choice of methodology depends on data availability and other characteristics. They also argue that alternative methods have excellent potential in pattern recognition and that they are competitive with more advanced methodologies such as logit regression.

In order to calculate the CQS, we use the degree of importance of the covenants (as perceived by bondholders who completed the questionnaire) as the weighting (see Table 4) and multiply this weighting by the extensiveness of the covenants used by the sample firms (from Table 3) to obtain the CQS for each issuer. From this CQS, we find the $25^{\text {th }}$ percentile (first quartile), median (second quartile), and $75^{\text {th }}$ percentile (third quartile) CQS for the whole population. We then group the sample firms into four quartiles: Group D are issuers who have CQSs less than 3.32 (very low protection); Group C are issuers with a CQS between 3.32 to less than 9.93 (low protection); Group B are issuers with a CQS between 9.93 to less than 21.24 (moderate protection); and Group A are issuers with a CQS of 21.24 and above (very high protection). Table 5 presents the breakdown of our sample firms into the four groups, based on the CQS.

As can be seen in Table 5, we find that, of the 29 issuers, almost half (14 issuers) can be categorised as bonds with low protection. When we assess the average returns offered to

\footnotetext{
${ }^{19}$ Moody's defines CQ-1 as strong investor protection, CQ-2 as good investor protection and CQ-3 as weak or no investor protection.
} 
bondholders, those bonds with low protection offer only $8.4 \%$ compared to the $9.2 \%$ offered by the high protection bonds (the difference is statistically significant at $10 \%$ level); holders of lower protection bonds are not compensated for the additional risk they take. These results contradict the dictum 'the higher the risk, the higher the return'. Thus, this study offers some evidence of the mispricing of bonds. The above findings also suggest that some form of CQS is a relevant research direction and can be a valuable contribution to the assessment of riskreturn trade-off for corporate bonds. 
Table 5 - Companies by Covenant Quality Score

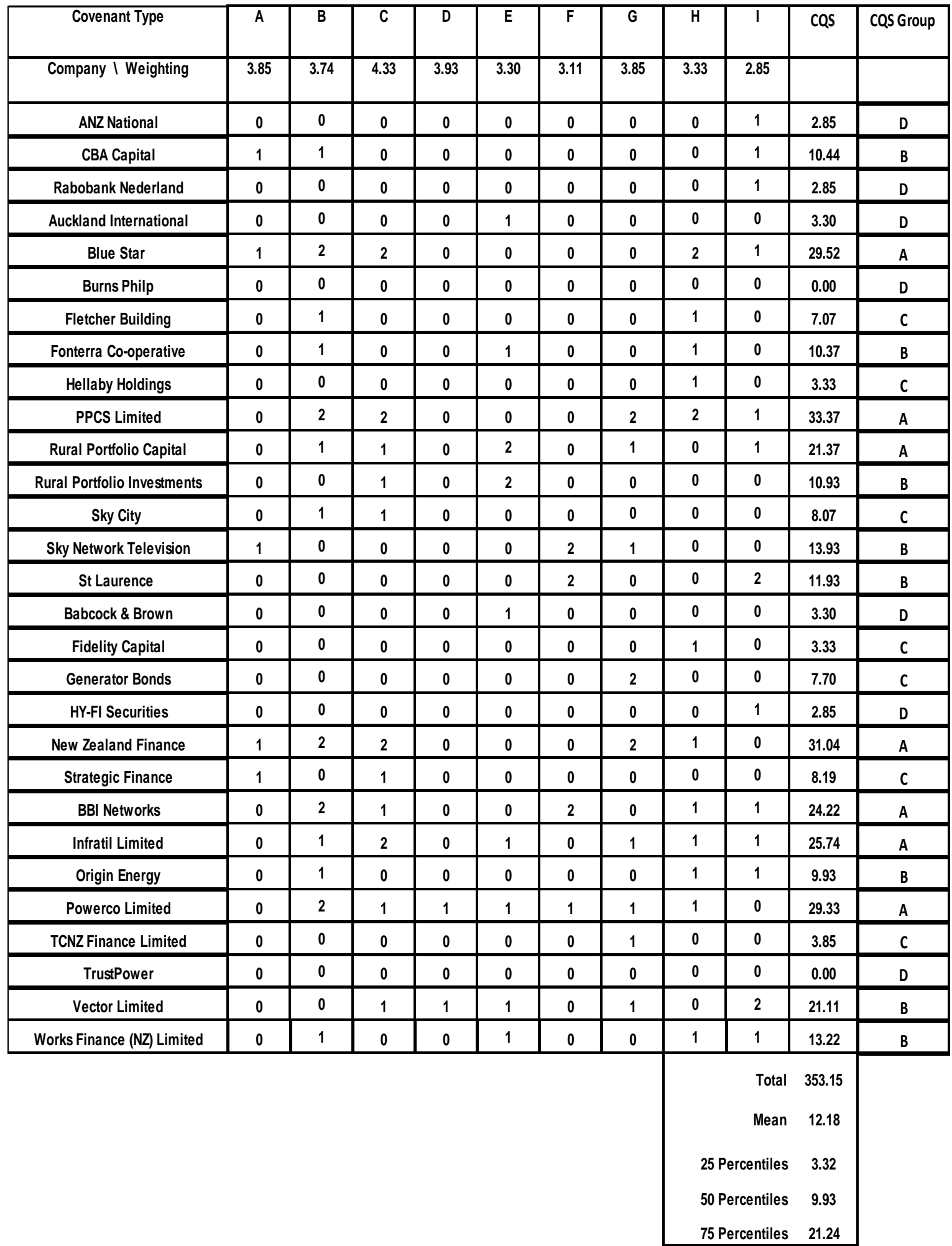

\section{Summary and Conclusion}

Restrictive covenants may be embedded in bond issues to give potential investors some comfort that the issuers will not behave to the detriment of investors' interests. However, if managers are embedding only restrictive covenants which they know the company will have 
very low risk of defaulting on, then the real protection that restrictive covenants can provide to bondholders will be manipulated, and is therefore meaningless. By such creative drafting of restrictive covenants in their investment policies, financing policies and bonding activities, companies still can expropriate funds from bondholders to its shareholders.

Using a sample of 29 bond issuers in NZ, we examine the extensiveness of the restrictive covenant embedded with their bond issues. We find that the bonds issued in NZ offer very limited protection to bondholders, and the protection that is provided is not deemed by bondholders to be important.

As the quality of bond covenant is an important input to the overall bond assessment, we have conceptualised a CQS and a bond-assessment framework incorporating it. In this process we compute the covenant quality score for each bond issue in our sample and group them into four covenant quality categories (A to D): four protection levels from very high, moderate, low to very low. Moody's (2006) has proposed a framework for the evaluation of the relative quality of each key covenant individually in a package and of the covenant package as a whole, assigning a score of CQ-1 to CQ-3 to the indenture. We extend this concept and introduce CQS as an input to the bond-assessment framework.

Along with the Securities Market Act which came into force on February 292008 and the establishment of the FMA in 2010, in part to govern the actions of investment advisers and market participants, an alternative framework may be a good complement to traditional credit ratings, to assist investors in making their investment decisions, especially in light of the recent financial crisis.

\section{References}

Aghion, P \& Bolton, P 1992, 'An incomplete contracts approach to financial contracting', Review of Economic Studies, vol.59, pp473-494.

Berlin, M \& Loeys, J 1988, 'Bond covenants and delegated monitoring', Journal of Finance, vol.42, no.2, pp397-412.

Billett, M, King, T \& Mauer, D 2007, Growth opportunities and the choice of leverage, debt maturity and covenants. Journal of Finance, vol.62, no.2, pp697-730.

Black, S, Brassil, A \& Hack, M 2010, 'The impact of the financial crisis on the bond market', accessed 10/6/2011, www.rba.gov.au/publications/bulletin/2010/jun/pdf/bu-0610-8.pdf

Bradley, M., \& Roberts, M. 2004, 'The structure and pricing of corporate debt covenants', Working paper, Duke University.

Chava, S \& Roberts, M 2008, 'How does financing impact investment? The role of debt covenants”, Journal of Finance, vol.63, no.5, pp2085-2121.

Dalziel, L 2007, Govt acts to improve finance company regulations. September, accessed 5/10/2007, www.beehive.govt.nz/Print/PrintDocument.aspx?DocumentID=30655

Denis, D \& Mihov, V 2003, 'The choice among bank debt, non-bank private debt, and public debt: Evidence from new corporate borrowings', Journal of Financial Economics, vol.70, no.1, pp3-28.

Dewatripont, M \& Tirole, J 1994, 'A theory of debt and equity: diversity of securities and manager-shareholder congruence’, Quarterly Journal of Economics, vol.109, pp10271054.

Diplock, J 2010, Chairmans' Report - The Last 12 Months have been Among the Most Significant in the History of New Zealand's Financial Market Regulation, accessed 10/6/2011, www.fma.govt.nz/media/25223/ann-rep-10.pdf 
Financial Market Authority 2010, Status of Investigations into Failed Finance Companies (Non-Bank Deposit Takers), accessed 10/6/2011, http://www.fma.govt.nz/laws-weenforce/enforcement/prosecutions-and-proceedings/status-of-investigations-intofailed-finance-companies-(non-bank-deposit-takers)/

Grant, D 2010, Stock Market - First Stock Exchange. Te Ara - the Encyclopedia of New Zealand, accessed 5/3/2010 http://www.teara.govt.nz/en/stock-market/1

Gorton, G \& Kahn, J 2000, 'The design of bank loan contracts', Review of Financial Studies, vol.13, pp331-364.

Guay, W 2008, 'Conservative financial reporting, debt covenants and the agency costs of debt', Journal of Accounting and Economics, vol.45, pp175-180.

$\mathrm{Hu}, \mathrm{H}$ \& Black, B 2008, Debt, equity and hybrid decoupling: governance and systematic risk implications', European Financial Management,vol.14, no.4, pp663-709.

International Monetary Fund, 2004, New Zealand: Financial System Stability Assessment. IMF Country Report, 04/126.

Jensen, M \& Meckling, W 1976, 'Theory of the firm: Managerial behavior, agency costs and ownership structure. Journal of Financial Economics, vol3, no.4, pp.305-360.

McIlroy, C 2000, Developers Find Intelligent Llife in Growing Junk Bond Market, accessed 12/9/2010, http://www.sharechat.co.nz/article/ac924ae9/developers-find-intelligentlife-in-growing-junk-bond-market.html

Moody’s Investors Service, Global Credit Research 2006, Moody's Indenture Covenant Research \& Assessment Framework, accessed 12/9/2010 www.treasurers.org/system/files/MoodyCovenentAssessmentconsultationSept06.pdf

Nash, R, Netter, J \& Poulsen, A 2003, 'Determinants of contractual relations between shareholders and bondholders: Investment opportunities and restrictive covenants', Journal of Corporate Finance, vol.9, pp201-232.

Rodgers, C. 1965, The Corporate Trust Indenture Project. Business Lawyer, 20, pp 551-571.

Smith, C \& Warner, J 1979, 'On financial contracting: An analysis of bond covenants', Journal of Financial Economics, vol.7, pp117-161.

Standard \& Poor's 2009, Guide to Credit Rating Essentials, accessed 10/8/2010 http://www.AboutCreditRatings.com

Tirole, J 2006, The Theory of Corporate Finance. Princeton University Press, Princeton.

Tripp, C 2010, The FMA Bill - The Shape of Things to Come, accessed 10/6/2011, http://www.lawfuel.co.nz/releases/release.asp?NewsID=2074

Tyler, S 2006, Developing Corporate Bond Markets in Asia. accessed 10/6/2011, http://www.bis.org/publ/bppdf/bispap26q.pdf

Vojtek, M \& Kocenda, E 2006, 'Credit scoring methods', Czech Journal of Economics and Finance, vol 56, no.3-4, pp152-167.

Whitehead, C 2009, 'The evolution of Debt: Covenants, the credit market and corporate governance', The Journal of Corporation Law, vol.34, no.3, pp641-677.

Yahanpath, N \& Bellard, R 2004, 'Protective covenants of New Zealand bond issues. New Zealand Journal of Applied Business Research, vol.3, pp75-85. 